\title{
The ECHR condemns prison overcrowding in Italy: The total reorganization of the institution and the social reintegration of the prisoner
}

\author{
by MARIA GARRO \& FEDERICA CIRAMI \\ University of Palermo (Italy)
}

\begin{abstract}
This contribution analyses the current Italian prison system, which has been called upon to resolve its structural problems. In 2013, The Council of Europe condemned Italy for inhuman treatment in its prisons. The principal accusation concerns the problem of overcrowding. The country has responded with solutions such as the application of the open system, which provides cells that are used exclusively for sleeping in at night, and dynamic monitoring, an effective system for ensuring order in the institutions. These initiatives aim to promote re-educational activities and the social re-integration of prisoners. In addition, Italian institutions have made greater use of alternatives to custodial penalties in order to tackle overcrowding and to provide more opportunities for re-integration. This contribution focuses on the need to increase prisoners' employment opportunities. In fact, Italy seems to have neglected this area, which is fundamental for re-integration into the community sphere.
\end{abstract}

Keywords: correctional education; re-entry; prisoner; organization

\section{Introduction}

The Italian prison system and the work of its operators have been the subject of numerous studies and debates that have analyzed them through different perspectives, such as political, social and legal approaches (Cellini, 2013). The prisoner context is actually a subsystem which strongly depends on the country in which it is sited. It is hugely influenced by the pressure of the mass media and by the socio-cultural context, which recognizes it as a punitive system whose purpose is to "normalize" deviance, identify "rejects" and attempt to correct them (Ferrara, 2013). As a consequence, there is a need for convicted persons to be treated in ways that respect their dignity. This is what happened until the reform of the penitentiary system in 1975 (L.354 / 75 - Norms on the penitentiary and on the enforcement of measures involving deprivation or limited freedom). This reform identified the presence of conditions in society that can lead the individual to commit a crime. This approach aims to overcome the idea that the only person responsible for the crime is the individual who commits it (Sarzotti, 2015).

The prison institutions have been examined in terms of organization as well as a way of structuring social actors who follow a set of rules and an internal, peripheral organization, whose aim is the achievement of goals (De Nardis, 1998; Buffa, 2013). It would be insufficient to talk about normative changes concerning the prison system without examining in depth the impact of changes in perspective on the organization of the daily work of all operators and the individual well-being of prisoners.

However, the current reality is that the Italian penitentiary system has structural problems, especially in terms of the health and safety of the prison population. The increase in the number of prisoners in the institutions led to a gradual deterioration of living conditions, reduced the effectiveness of rehabilitation and hampered relations with the outside community. For these reasons, in 2013 the European Court of Human Rights (ECHR) condemned Italy for inhuman treatment and overcrowding in prison facilities, accusing the State of violating Art. 3 (prohibition of torture and inhuman or degrading treatment) of the ECHR. 


\section{The penitentiary change after the ECHR's condemnation}

After the ECHR's judgment, the Italian prison system started the process of change. The country is committed to changing the layout of prisons because the buildings themselves contribute to poor conditions. Firstly, attention has been directed towards the creation of a new organizational and management system for the entire system. Secondly, the institution has aimed to improve the appreciation of prison workers who perceived the negative judgment of the Council of Europe as a personal defeat.

In response to these factors, the Italian system is committed to ensuring the welfare of prisoners, harmonizing disparate regulations and operational practices. In fact, "despite the coercive character of the institution, it is considered that there are limits for the prison population regarding the protection of individuals and their rights through the acquisition of skills which useful to internal survival and which are gradually applied to the phase of re-integration" (writer's translation, www.ristretti.it). The reformation of 1975 focused on the centrality of developing relationships with the prison population; however, it is true that over the years the dimensions of the prison system, both in space and time, have represented very critical elements for achieving the objective of the legislator.

Currently, the main response to this issue is the application of a so-called open regime (described in Art. 6 of the Penitentiary of 1975) which ensures better living conditions for private individuals deprived of personal liberties. According to this reform, the cell is used exclusively for sleeping in at night. During the day, education, training, employment, and leisure take place in other specific spaces, whereas the courtyards are for time 'out of cell'. In addition, there are specific places for meetings with professionals and for their meals.

Furthermore, the dynamic monitoring concept is closely related to this approach. In fact, it consists of the simplification, rationalization, and qualification of workloads, the distinction of levels of expertise, and the sharing of information flows between the various professionals. This is a dynamic security service capable of reconciling order within the prisons with helpful psychological and pedagogical activities.

The foundation of dynamic monitoring is based on close relationships between prisoners and prison staff, which can be severely limited if the prisoners' physical space remains confined to a few square meters in the cell. Therefore, it is important to achieve effective communication between the various professionals involved in observation and treatment. The success of the aforementioned goals depends on effective communication between the professionals who work in the field of observation and treatment, coupled with the assignment of workloads dependent on the human and material resources of each institution. In addition, it is important that prison staff get to know prisoners and help develop a sense of responsibility, enhancing the quality of the relationships among prisoners, and between prisoners and staff.

These factors emphasize the high level of attention focused on the protection of the dynamics between professional workers and prisoners' rights.

\section{The prison population in the new organization}

Operational strategies adopted in response to the ECHR's requirements ask for a review of the organizational and management system of penitentiary administration through the shared commitment of the entire prison population. What is required is a strong sense of responsibility that gives all professionals who work respectively in and for the prison, whether they are organized or not, the opportunity to address this important change. The open prison system and dynamic monitoring, which can only take place through the active involvement of the staff and prisoners, implies renewed flexibility and expertise as part of a reorganization of the management and security (i.e. greater autonomy in the management of their resources, of security and of the cognitive processes of the prisoners) (www.giustizia.it).

The success of the prison organization lies with its human resources, which demands a good relational atmosphere within the work context (Nelli, 1994), attention to relationships and also to employees' motivations (Avallone \& Bonaretti, 2003).

These new applications can disorient all prison actors who can have difficulties in changing their modus operandi. In fact, the prison institution is a rigorous system resistant to change. In particular, prison work- 
ers have some difficulties in changing their approach while some prisoners seem to accept the changes. During research in prisons conducted by the writer, some prisoners expressed an acceptance of the changes thanks to the greater freedom of movement and contact between cells. Prisoners, in fact, recognize relational needs as existential needs. In particular, this occurs within the open regime system when prisoners are migrants because it gives them the chance to restore ethnic and cultural traditions.

The new system also requires an increase in employment opportunities for prisoners at the beginning of their sentences as opposed to at the end. However, this opportunity is limited because of the insufficient number of jobs available and this hampers the process of social re-integration.

The transition from prison to the community is often a complex process that depends on the need for social security and the need for ex-prisoners to become active members of the community, moving beyond their labels as prisoners (Skowronski \& Carlson, 1989; Maruna \& Immarigeon, 2004). In this regard, the alternatives to incarceration, called community sanctions, are good examples of alternatives to punishment and treatment. The community sanctions include measures such as probation, home detention and custodial sentences $^{1}$, which allow part-time study or work outside the prison, experiencing outside life instead of isolation and avoiding the overcrowding of prisons. These activities are based mainly on the possibility of working outside the prison, an important opportunity to develop their awareness of social assistance and to deal with dynamics similar to those that they will face outside prison. In this way, the work becomes a tool for the gradual preparation for a free life: the prisoner begins to perceive themselves useful to society, capable of creating a system of relations and designing a life outside their cell.

Subsequently, it is important to highlight that there are many limitations in realizing long-term projects due to high levels of unemployment and poverty. In fact, in Italy the phenomenon of the working poor (Lavanco \& Novara , 2017) which emerged in the late eighties (Crettanz \& Bonoli, 2010), is more widespread among young people and marginal subjects (former prisoners, former drug addicts, ex-alcoholics). Firstly, the main problem regards the effects of low wages, provoking consequently poor education and training, poor health, widespread crime, poverty and social exclusion. Job insecurity affects ex-prisoners doubly because the community treats them as second-class workers, aggravating the social re-integration processes. Actually, in the Italian context, the region of Sicily registers the highest rate of precarious employment, unemployment, poverty and the greatest concentration of social exclusion.

In order to reduce the extent of these difficulties, the Italian system should begin to meet the prerequisites for prisoners/ex-prisoners' re-integration to work. A good solution would be the establishment of a special employment office that is responsible for finding employment compatible with the profile of the prisoner/ex-prisoner. Furthermore, it is important to carry out the procedures laid down by the law and harmonize the bureaucracy, considering that prison overcrowding causes the transfer of prisoners within and between regions. In December 2016, two years after the ECHR's recommendations, the official national capacity of the prisons amounted to 50,228 places compared with 54,653 prisoners in attendance. Furthermore, there is a need to provide a service to prisoners in order to obtain the personal documents required for employment, ensuring the respect of their fundamental rights (www.ristretti.it).

\section{Conclusions}

The prison reorganization requested by the ECHR calls for the active involvement of workers and prisoners. Many initiatives have been planned for the enrichment of professional skills and for the social inclusion of prisoners (www.giustizia.it), such as active listening (Caputo, 2013). However, there is a need to enhance the relationship between the staff and the prison population in order to protect the community needs in which the prisoner has the right of re-integration. Furthermore, the institution has to "humanize" the prison system. Pris-

${ }^{1}$ 1) Prisoners are placed in the custody of social services outside the prison for a period that is equal to the term of imprisonment. 2) Female prisoners who are pregnant or who have children (under the age of 10) can serve their sentence in their own home, in another private house or in public centers that assist women in disadvantaged conditions. 3) The prisoner spends part of the day outside of the prison in order to participate in work, educational activities or other activities useful to their social re-integration, on the basis of a treatment program, the responsibility of which is entrusted to the director of the penal institution (Official Journal of the European Communities, No. R (92) 16). 
ons should not be considered merely as places of imprisonment; rather, they should be considered as 're-educational' places, which aim to improve quality of life. However, this mission has sparked controversy due to the difficulty in changing the perspective of many of those who operate within the system. Problems still exist regarding the social resistance toward the re-integration of ex-prisoners into the community, which risks creating the foundation of a dichotomy that a prisoner is "locked out of the jail" because they are perceived as a 'foreign body' and not as an integral part of society. This distorted view encourages the reality of the prison as a closed community: a dysfunctional element that mainly threatens southern Italy because of its additional social problems (unemployment, poverty, and criminality).

Currently, it is not possible to draw up a complete assessment of the Italian prison system. Otherwise, it seems appropriate to examine and reflect on what has already been achieved and what improvements still have to be made in order to improve the well-being of the prison population and to overcome the distance between the institutions and the social work.

\section{References}

Avallone, F. \& Bonaretti, M. (2003). Benessere Organizzativo: Per migliorare la qualità del lavoro nelle amministrazioni pubbliche. Roma: Rubbettino.

Buffa, P. (2013). Prigioni. Amministrare la sofferenza. Torino:Gruppo Abele.

Caputo, G. (2013). Il carcere degli stranieri: problematiche e aspetti gestionali nella pratica operativa della polizia penitenziaria. Dispense ISSP, 2, settembre. Retrieved from http://www.ristretti.it/commenti/2013/ ottobre/pdf2/issp_dispensa2.pdf

Cellini, G. (2013). Controllo sociale, servizio sociale e professioni di aiuto. Una ricerca nel sistema penitenziario. Milano: Ledizioni.

Crettaz, E. \& Bonoli, E. (2010). Why Are Some Workers Poor? The Mechanisms that Produce Working Poverty in a Comparative Perspective. Working Papers on the Reconciliation of Work and Welfare in Europe, Rec-Wp 12/2010. Retrieved from http://ssrn.com/abstract=1691662

De Nardis, P. (1998). Istituzione come organizzazione. In C. Serra (Eds), Istituzione e comunicazione. Segni e simboli della rappresentazione sociale del carcere (pp.17-24). Roma: SEAM.

Ferrara, $\cdot$ V. (2013). Il lavoro penitenziario: la dimensione umana del carcere e della città che lo accoglie. L'esperienza della cooperativa sociale Rio Terà dei Pensieri. Rivista di Criminologia, Vittimologia e Sicurezza - Vol. VII - N. 3 - Settembre-Dicembre 2013. Retrieved from http://www.vittimologia.it/rivista/ articolo_ferrara_2013-03.pdf

Lavanco G. \& Novara C. (2017). Comunità chiuse, comunità aperte: rimanere chiusi “fuori”dal carcere. In M. Garro e F. Pace (a cura di). Sorveglianza dinamica e regime aperto. Cambiamenti normativi, organizzativi e psicosociali. Milano: FrancoAngeli. pp.155-174.

Maruna, S., Lebel, T.P,, Mitchell, N. \& Naples, M. (2004). Pygmalion in the reintegration process: desistance from crime through the looking glass. Psychology, Crime \& Law, 10 (3), 271-281. doi: $10.1080 / 10683160410001662762$.

Nelli, R. (1994). La comunicazione interna nell'economia dell'azienda. Milano: Vita e Pensiero.

Sarzotti, C. (2015). La riforma dell'ordinamento penitenziario come narrazione giuridica del carcere negli anni della "scoperta" della Costituzione. Questione giustizia, 2, 23-33. Retrieved from http://www.questionegiustizia.it/rivista/pdf/QG_2015-2_05.pdf

Skowroński, J.J, \& Carlson, D.E. (1989). Negativity and extremity biases in impression formation: a review of explanations. Psychological Bulletin, 105 (1), 131-142. doi.apa.org/journals/bul/105/1/131.pdf 
Maria Garro is a psychologist and senior researcher in Social Psychology - University of Palermo. She writes and presents on issues regarding inmates, rehabilitation, and reintegration. She trains in the area of forensic psychology.

Federica Cirami is a PhD Student in European Cultural Studies at the University of Palermo. Her research focuses on Gender Studies, gender-based violence, gender stereotype, prejudice and discrimination. In particular, she conducts research on suffering, women's resilience ability and empowerment's ability in conflict's areas. 